\title{
Development of a Scale for Evaluation of Tomato yellow leaf curl virus Resistance Level in Tomato Plants
}

\author{
M. Lapidot, R. Ben-Joseph, L. Cohen, Z. Machbash, and D. Levy
}

First, second, third, and fourth authors: Department of Vegetable Research, Institute of Plant Sciences, Agricultural Research Organization, Volcani Center, Bet Dagan 50250, Israel; and fifth author: Hazera Genetics, Mivhor, M.P. Lachish Darom, 79134, Israel. Accepted for publication 26 July 2006.

\begin{abstract}
Lapidot, M., Ben-Joseph, R., Cohen, L., Machbash, Z., and Levy, D. 2006. Development of a scale for evaluation of Tomato yellow leaf curl virus resistance level in tomato plants. Phytopathology 96:1404-1408.

We have developed a scale of differential hosts that enables the determination and comparison of level of resistance to Tomato yellow leaf curl virus (TYLCV) expressed by resistant tomato lines or by individual plants in a segregating population. The scale is composed of seven different homozygous tomato genotypes that exhibit different levels of TYLCV resistance, ranging from fully susceptible to highly resistant. The differential hosts composing the scale were inoculated with TYLCV under green-

different genotypes were arranged in the scale according to symptom severity score. The different genotypes were then tested under different environmental conditions, inoculated at different ages, and tested in a field experiment assaying TYLCV-induced yield reduction. While the symptom severity score of each individual resistant genotype changed under different environmental conditions, the relative position on the scale did not alter, except for one genotype. Thus, to evaluate disease resistance of a given tomato genotype, the genotype in question should be inoculated alongside the differential hosts composing the scale, and within 4 weeks one can determine the relative level of resistance of the tested genotype.
\end{abstract} house conditions. Four weeks after inoculation the plants were evaluated for disease symptom severity, and virus DNA titer was determined. The
Additional keywords: begomovirus, Lycopersicum esculentum.
Tomato yellow leaf curl virus (TYLCV) is currently one of the most devastating viruses of cultivated tomatoes in tropical and subtropical regions. Although originally found in the eastern Mediterranean (3), it is now a problem in the western Mediterranean, the Caribbean, Japan, and the southern United States $(18,19)$. The virus is a monopartite begomovirus, transmitted by the whitefly Bemisia tabaci (Gennadius) whose severe population outbreaks are usually associated with high incidence of the disease. Control measures in infected regions are traditionally based on limiting vector population. Chemical control has been only partially effective, especially under high disease pressure, and in addition to its deleterious effects on the environment, the vector has been shown to develop pesticide resistance $(6,13)$. The use of fine-mesh screens has become widespread in the Mediterranean Basin as a means of crop protection (2). Recently, UV-absorbing plastic sheets and screens have been shown to inhibit penetration of whiteflies into greenhouses (1). However, these screens create problems of overheating and poor ventilation. Genetic resistance in the host plant is an ideal defense against whitefly-transmitted viruses, since it requires no chemical input and/or plant seclusion and may be stable and long lasting. Thus, the best way to reduce the spread of TYLCV is by breeding tomatoes resistant or tolerant to the virus (7).

Over the last 25 years there has been an extensive effort to breed tomato cultivars resistant to TYLCV. Since all cultivars of tomato (Lycopersicon esculentum L.) are extremely susceptible to TYLCV, wild Lycopersicon species were screened for response to the virus to identify genes for resistance $(7,10,11,15,16)$. Breeding programs have been based on the transfer of resistance genes from accessions of wild origin into the cultivated tomato. Inocu-

Corresponding author: M. Lapidot; E-mail address: lapidotm@volcani.agri.gov.il

DOI: 10.1094/PHYTO-96-1404

(C) 2006 The American Phytopathological Society lation of wild tomato species, in the search for new sources of resistance, was shown to be most effective when carrying out individual inoculation of different wild tomato species in cages, since accessions of some wild species could escape infection due to nonpreference by whiteflies $(4,14)$. Progress in breeding for TYLCV resistance has been slow, due in part to the complex genetics of the resistance and the presence of interspecific barriers between the wild and domesticated tomato species.

Another major obstacle in the development of TYLCV resistance has been the lack of a standard method for the assessment of resistance. Thus, due to the lack of a standard for resistance assessment, resistance level is usually decided based on the severity of disease symptoms induced by the virus. However, plant age at the time of infection, inoculation pressure, and growth conditions can have a major effect on disease symptom severity $(9,14)$. Thus, variability in assay conditions has led to contradictory results, where different resistance levels were attributed to the same genetic sources $(14,15,20)$. In addition, the performance of at least some of these resistance genes appears to be influenced by environment such that large differences in resistance performance were found when a number of TYLCV-resistant cultivars were compared under different environmental conditions $(9,14)$. Yield reductions caused by TYLCV were twice as great when the tomato plants were evaluated in the field in a hot season than when they were evaluated in a greenhouse in a cooler season $(9,14)$. Hence, the different performances received from the same cultivars when tested under different conditions can be misleading and can frustrate efforts to select for the best TYLCV resistance from a segregating population.

Another setback in the development of TYLCV resistance is that while most screening assays rely on severity of TYLCV-induced disease symptoms, the most relevant evaluation of resistance level is TYLCV-induced yield reduction. Since the genetic background of the tested cultivar is of importance as well as the resistance genes, it is recommended to test the effect of infection 
on total yield and yield components, and not only symptoms, compared with that of equivalent noninfected plants (8). Usually, tests comparing different cultivars are carried out under field inoculation, and no comparison is made to the full yield potential of uninfected plants, which has a direct bearing on the yields of the infected plants. Nevertheless, such expensive and time-consuming tests can only be carried out on the most promising resistant cultivars, not on segregating populations.

To overcome the above difficulties, a series of differential TYLCV-resistant tomato hosts was developed that enables the comparison of TYLCV resistance level expressed by resistant tomato plants. Using the scale, TYLCV resistance level in a segregating population and/or in stable resistant lines can be determined as quickly as 4 weeks following inoculation. Moreover, the scale can be used either in a controlled environment such as a greenhouse or under field conditions. The scale comprises seven different homozygous tomato genotypes that exhibit different levels of TYLCV resistance, ranging from fully susceptible to highly resistant. The differential hosts were inoculated with TYLCV under different environmental conditions and different plant age and compared in greenhouse and field evaluation.

\section{MATERIALS AND METHODS}

Virus, whitefly maintenance, and virus inoculation. Cultures of the Israeli isolate of TYLCV (12) (GenBank accession no. $\mathrm{X} 15656)$ were maintained in tomato (L. esculentum) in an insectproof greenhouse. Whitefly (Bemisia tabaci, biotype B) colonies were reared on cotton (Gossypium hirsutum L.) plants grown in muslin-covered cages maintained within an insect-proof greenhouse. Adult whiteflies were provided a 48-h acquisition access period on TYLCV-infected tomato source plants, after which they were provided a 48-h inoculation access period (IAP) on the scale tomato plants. To ensure $100 \%$ infection, the plants were inoculated at the first-leaf stage, 50 whiteflies per plant. Control, noninoculated plants of the same lines were exposed to virusfree whiteflies for $48 \mathrm{~h}$. Following the IAP, whiteflies were removed by treating plants with imidacloprid (Confidor, Bayer, Leverkusen, Germany) and plants were maintained in an insect-proof greenhouse at 26 to $32^{\circ} \mathrm{C}$ until symptom development.

Plant material. The differential hosts composing the scale of TYLCV resistance (STY) are all nonsegregating lines. Some were derived from commercial hybrids by a process of screening and selection-plants were selfed, progeny plants were inoculated with TYLCV, and following a screen the selected plants were selfed again, and then screened again. The screen-selection process continued until the plants segregation for the resistance ceased, usually after four to five generations. The scale was composed of the following lines: STY-1, a susceptible 'Marmande' type tomato line, R-13 (Hazera Genetics Ltd., Brurim, Israel); STY-2, derived from the TYLCV-resistant hybrid 8484 (Hazera Genetics) following four generations of screen and selection; STY-3, derived from the TYLCV-resistant hybrid Fiona (S\&G, Enkhuizen, The Netherlands) following five generations of screen and selection; STY-4, derived from the TYLCV-resistant hybrid 3761 (A.B. Seeds, Israel) following four generations of screen and selection; STY-5, derived from the TYLCV-resistant hybrid Tyking (Royal Sluis, Enkhuizen, The Netherlands) following five generations of screen and selection; STY-6, a Volcani Center TYLCV-resistant breeding line, TY-197 (8); and STY-7, a Volcani Center TYLCV-resistant breeding line, TY-172 (8).

TYLCV symptom severity rating. Symptom development was evaluated according to the symptom severity scale described by Friedmann et al. (5) as follows: $0=$ no visible symptoms, inoculated plants show same growth and development as noninoculated plants; 1 = very slight yellowing of leaflet margins on apical leaf; 2 = some yellowing and minor curling of leaflet ends;
3 = a wide range of leaf yellowing, curling and cupping, with some reduction in size, yet plants continue to develop; and $4=$ very severe plant stunting and yellowing, pronounced leaf cupping and curling, and plant growth stops (5). Plant height is given as the percentage of the control plant height that the inoculated treatment achieved, i.e., height of inoculated plants divided by the height of the uninoculated control plants $\times 100$.

Field trial. Following controlled inoculation in the greenhouse, the plants were transplanted to the field in April, and were in the field through the spring and summer seasons. Prior to transplanting, the plants were treated with imidacloprid. Plants of each STY line were planted in paired rows, inoculated and noninoculated (control), on 1-m-wide beds, five plants per row. The within-row and between-row spacing were 0.5 and $1.2 \mathrm{~m}$, respectively. Each pair of rows served as a replicate of the experiment, and a total of 10 randomly distributed replicates were planted in the field. Imidacloprid was applied through the drip irrigation system at 4 and 8 weeks after transplanting. Fruits were picked in three harvests: in the first and second harvests, all mature red fruits were collected; and in the third harvest, all mature red and immature green fruits were collected. Culls were discarded. The following parameters were assayed: total yield, total number of fruits, and average fruit weight. Data were taken per row and were averaged for all rows.

Viral DNA detection. Viral DNA accumulation level in the uppermost leaf of infected source plants of each variety was estimated by dot blot hybridization. Leaf tissue samples $(0.1 \mathrm{~g})$ from the plant apex were ground in $0.5 \mathrm{ml}$ of $0.4 \mathrm{M} \mathrm{NaOH}$, and $10-\mu l$ samples were dotted on a nylon membrane, as described previously (8). For background determination, samples were taken from healthy noninoculated control plants of each line. TYLCV cDNA served as a template for the production of an in vitro-synthesized ${ }^{32} \mathrm{P}$-labeled viral riboprobe corresponding to the full-length viral genome. The membrane was reacted with the labeled viral riboprobe, washed, and exposed to a phosphorimager screen (Bio-imaging analyzer, BAS-1500, FUJIFILM, Japan). The amount of viral single-stranded DNA in each spot was quantitated and the background level was subtracted from each measurement. The amount of TYLCV DNA in each sample was calculated according to a standard curve of TYLCV cDNA (ranging from 1 to $100 \mathrm{ng}$ of TYLCV cDNA), which was dotted on a nylon membrane and reacted with the labeled viral riboprobe. TYLCV DNA level in the infected TYLCV scale plants determined by dot blot hybridization is expressed as the percentage of DNA in the susceptible (STY-1) plants, which was equated to $100 \%$.

Statistical analysis was done by means of a one-way analysis of variance test (SAS Institute, Cary, NC).

\section{RESULTS}

Response of scale plants to inoculation with TYLCV. The TYLCV scale plants were inoculated with TYLCV at first true leaf stage. Following inoculation, the plants were kept in a greenhouse for 4 weeks when disease-induced symptoms were fully developed. The plants were then scored for TYLCV-induced symptom severity, viral DNA level in the inoculated plants was assayed, and plant height was measured (Table 1). The STY-1 line, which is TYLCV-susceptible, received a score of 4 . The score of the other STY lines ranged from 3.4 (STY-2) to 0.2 (STY-7) (Table 1). The different lines were arranged in the scale according to their symptom severity score. When viral DNA level was assayed in the TYLCV scale lines, the results matched the order of the symptom severity scores: the highest level of viral DNA was detected in plants of the STY-1 line, less in STY-2 and STY-3, and very low levels were detected in STY-4 to STY-7 lines (Table 1). There were no significant differences in viral DNA levels between STY-4 and STY-7 lines, despite clear dif- 
ferences in the symptom severity scores of these plants. This is consistent with previous findings showing that lines with high levels of resistance to TYLCV accumulated similar levels of viral DNA (8). However, when TYLCV-induced plant height reduction was assayed, no clear correlation was found between height reduction, viral DNA level, and severity of symptoms (Table 1).

To test if the TYLCV scale lines would react to TYLCV inoculation under different conditions in the same manner, the plants were inoculated at two different ages, 10 and 21 days (Table 2). The susceptible line (STY-1) reacted the same to TYLCV inoculation regardless of plant age at time of inoculation. Unlike the susceptible line, all the resistant lines (STY-2 to STY-7) showed milder symptoms following inoculation of 21-day-old plants compared with inoculation of 10-day-old plants (Table 2). However, despite the improvement in the disease scores exhibited by the different resistant lines, their order within the scale did not change.

The effects of environmental conditions were also tested by inoculating and scoring the TYLCV scale lines in the summer (July, high temperature and intense light) and in the winter (December, low temperature and light) (Table 3). The susceptible line (STY-1) and the less resistant lines (STY-2 and STY-3) showed lower levels of symptom severity following winter inoculation compared with summer inoculation, the latter being TYLCV preferred conditions (Table 3). The lines that exhibited higher levels of TYLCV resistance (STY-4 to STY-7) were only slightly affected by the different seasons and performed practically the same in both seasons (Table 3). With the exception of STY-3, the order within the scale did not change in response to the change of season.

Field test of scale plants. The TYLCV scale lines were tested in the field for TYLCV-induced yield reduction. The plants were transplanted to the field following inoculation in the greenhouse. The inoculated plants of each TYLCV scale line were compared with noninoculated control plants of each line, which had been exposed to virus-free whiteflies, in terms of total yield, average fruit number, and fruit size (Table 4). When the order of the different lines was examined according to TYLCV-induced yield reduction, the order of the scale lines did not change, except for STY-3 plants. The yield loss of susceptible STY-1 plants was $97 \%$ of the potential yield, that of STY-2 plants was $81 \%$, STY-3 plants $65 \%$, STY-4 plants $76 \%$, STY-5 plants $54 \%$, STY-6 plants $48 \%$, and STY-7 plants $45 \%$ (Table 4). Apparently, with the exception of the STY-3 line, the order of the STY lines according to disease symptom severity matched the order of TYLCV-induced yield reduction.

The yield reduction in all the tested lines was due mainly to reduction in the number of fruit per plant following TYLCV inoculation. However, STY-1 STY-2, and STY-4 also suffered from reduction in fruit size, which contributed to the total reduction in yield, whereas STY-3, STY-5, STY-6, and STY-7 suffered (if at all) little fruit size reduction (Table 4).

\section{DISCUSSION}

A scale was developed that enables the determination and comparison of levels of resistance to TYLCV expressed by resistant tomato plants. The scale is comprised of seven different homozygous tomato genotypes that exhibit different levels of TYLCV resistance, ranging from fully susceptible to highly resistant. The genotypes in the scale were arranged according to symptom severity score, ranging from scale TYLCV number 1 (STY-1), which is susceptible and expressed severe disease symptoms, to STY-7, which is highly resistant and showed little, if any, disease symptoms. When viral DNA level was assayed in the scale plants, results were consistent with the symptom severity score - the highest level of viral DNA was detected in the susceptible (STY-1) line, less in the moderately resistant genotypes (STY-2 and STY-3), and very low levels of viral DNA were detected in the highly resistant genotypes (STY-4 to STY-7) (Table 1). However, there was no significant difference in viral DNA level among the highly resistant genotypes, despite clear differences in the symptom severity scores and in the TYLCV-induced yield reductions of these plants. This is consistent with previous findings showing that lines with high level of resistance to TYLCV accumulated similar levels of viral DNA (8).

The scale genotypes were tested under different conditions to see if the scale is indeed applicable in a variety of conditions. The scale genotypes were inoculated at two different ages, 10 and 21 days (Table 2), and all the resistant genotypes were less symptomatic following inoculation of 21-day-old plants than those inoculated at 10 days. However, the order within the scale remained the same despite the improvement of disease scores exhibited by the different resistant genotypes.

The effects of environmental conditions were also tested by inoculating and scoring the scale genotypes under summer conditions of high temperature and intense light, and under the low temperatures and low light intensity of winter conditions (Table 3 ). Again, most genotypes were less symptomatic in the milder winter conditions. However, with the exception of STY-3, the order within the scale was not affected by the seasonal conditions.

The scale genotypes were also tested for TYLCV-induced yield reduction, which is the ultimate test for viral (or any other patho-

TABLE 2. Effect of plant age at time of inoculation on Tomato yellow leaf curl virus-induced symptom severity

\begin{tabular}{lcc}
\hline & \multicolumn{2}{c}{ Symptom rating following inoculation of } \\
\cline { 2 - 3 } Genotype & 10-day-old plants & 21-day-old plants \\
\hline STY-1 & 4.0 & 4.0 \\
STY-2 & 3.4 & 2.5 \\
STY-3 & 3.2 & 1.5 \\
STY-4 & 2.1 & 1.2 \\
STY-5 & 1.3 & 0.5 \\
STY-6 & 0.8 & 0.5 \\
STY-7 & 0.2 & 0.0 \\
\hline
\end{tabular}

TABLE 1. Response of Tomato yellow leaf curl virus (TYLCV) scale lines to TYLCV inoculation ${ }^{\mathrm{x}}$

\begin{tabular}{|c|c|c|c|c|c|c|c|c|c|c|c|c|}
\hline \multirow[b]{2}{*}{ Genotype } & \multicolumn{9}{|c|}{ Symptom rating/repeat no. } & \multirow{2}{*}{$\begin{array}{c}\text { Average } \\
\text { score }\end{array}$} & \multirow{2}{*}{$\begin{array}{l}\text { Height } \\
(\%)^{\mathrm{y}}\end{array}$} & \multirow{2}{*}{$\begin{array}{c}\text { TYLCV } \\
\text { DNA }(\%)^{2}\end{array}$} \\
\hline & 1 & 2 & 3 & 4 & 5 & 6 & 7 & 8 & 9 & & & \\
\hline STY-1 & 4.0 & 4.0 & 4.0 & 4.0 & 4.0 & 4.0 & 4.0 & 4.0 & 4.0 & 4.0 & $47 a$ & $100.0 \mathrm{a}$ \\
\hline STY-2 & 3.5 & 3.5 & 3.0 & 3.5 & 3.5 & 3.5 & 3.5 & 3.5 & 3.4 & 3.4 & $48 \mathrm{a}$ & $45.7 \mathrm{~b}$ \\
\hline STY-3 & 3.0 & 3.0 & 3.5 & 3.5 & 3.5 & 3.0 & 3.0 & 3.0 & 3.0 & 3.2 & $60 a$ & $34.2 \mathrm{~b}$ \\
\hline STY-4 & 2.0 & 2.0 & 2.0 & 2.0 & 2.0 & 2.0 & 2.0 & 2.0 & 2.0 & 2.0 & $87 \mathrm{c}$ & $7.7 \mathrm{c}$ \\
\hline STY-5 & 0.5 & 1.0 & 1.0 & 1.0 & 2.0 & 1.0 & 1.0 & 2.0 & 2.0 & 1.3 & $73 \mathrm{~b}$ & $3.1 \mathrm{c}$ \\
\hline STY-6 & 0.0 & 0.5 & 0.5 & 0.5 & 0.5 & 1.0 & 0.5 & 1.5 & 1.5 & 0.8 & $62 \mathrm{a}$ & $6.9 \mathrm{c}$ \\
\hline STY-7 & 0.0 & 0.0 & 0.0 & 0.0 & 0.0 & 0.0 & 0.5 & 0.5 & 0.0 & 0.2 & $74 \mathrm{~b}$ & $5.5 \mathrm{c}$ \\
\hline
\end{tabular}

${ }^{x}$ Means with different letters differ significantly at $P<0.05$ when analyzed by one-way analysis of variance.

y Percentage of control (noninoculated) plants of the same line.

z Percentage of TYLCV DNA of the STY-1 line. 
gen) resistance. The yield of each infected scale genotype was compared with that of its control, uninfected counterpart, and again, except for STY-3 plants, the order of the TYLCV scale lines according to virus-induced yield reduction was the same as that according to the other criteria (Table 4). The scale genotypes express TYLCV resistances that originated from several different wild-type tomato species. STY-2 resistance originated from L. peruvianum (17), that of STY-6 and STY-7 originated from different L. peruvianum accessions $(5,8)$, and that of STY-3, STY4 , and STY-5 probably from L. chilense (15). Moreover, these tomato genotypes have different genetic backgrounds; for example, STY-2, STY-4, STY-5, and STY-6 were developed from determinate types, whereas STY-3 and STY-7 were developed from semideterminate plant types. These differences can affect the overall performances of the TYLCV scale genotypes in the field, and may account for the switch in the positions of STY-3 and STY-4 when the scale was arranged according to yield reduction.

It should be noted that the symptom severity scores of the scale genotypes were highly correlated with the TYLCV-induced yield reduction; with the exception of STY-3 plants, the order of the scale genotypes with respect to symptom severity was in agreement with the order of TYLCV-induced yield reduction. To the best of our knowledge, this is the first time such a correlation between symptom severity and yield reduction has been demonstrated.

The TYLCV resistance scale described here can be utilized as a standardization tool for the assessment of TYLCV resistance under diverse conditions. Moreover, it can be used in a controlled

TABLE 3. Effect of season on Tomato yellow leaf curl virus-induced symptom severity

\begin{tabular}{lcc}
\hline & \multicolumn{2}{c}{ Symptom rating following inoculation in } \\
\cline { 2 - 3 } Line & Summer & Winter \\
\hline STY-1 & 4.0 & 3.3 \\
STY-2 & 3.4 & 2.3 \\
STY-3 & 3.2 & 1.4 \\
STY-4 & 2.1 & 1.8 \\
STY-5 & 1.3 & 1.2 \\
STY-6 & 0.8 & 0.7 \\
STY-7 & 0.2 & 0.0 \\
\hline
\end{tabular}

TABLE 4. Effect of Tomato yellow leaf curl virus (TYLCV) on yield components of TYLCV scale lines grown in the field

\begin{tabular}{llccc}
\hline Line & & $\begin{array}{c}\text { Mean total yield } \\
\text { per plant }(\mathrm{kg})\end{array}$ & $\begin{array}{c}\text { Mean number of } \\
\text { fruits per plant }\end{array}$ & $\begin{array}{c}\text { Mean fruit } \\
\text { weight }(\mathrm{g})\end{array}$ \\
\hline STY-1 & Uninoculated & 4.8 & 30 & 160 \\
& Inoculated & 0.1 & 1.1 & 80 \\
& $P^{\mathrm{z}}$ & $<0.001$ & $<0.001$ & $<0.001$ \\
STY-2 & Uninoculated & 5.8 & 48.8 & 118 \\
& Inoculated & 1.1 & 14.3 & 78 \\
& $P$ & $<0.001$ & $<0.001$ & $<0.001$ \\
STY-3 & Uninoculated & 9.1 & 121.7 & 75 \\
& Inoculated & 3.2 & 44.3 & 72 \\
& $P$ & $<0.001$ & $<0.001$ & $>0.4$ \\
STY-4 & Uninoculated & 5.4 & 34.6 & 157 \\
& Inoculated & 1.3 & 11.6 & 110 \\
& $P$ & $<0.001$ & $<0.001$ & $<0.001$ \\
STY-5 & Uninoculated & 2.7 & 29.2 & 92 \\
& Inoculated & 1.2 & 13.2 & 90 \\
& $P$ & $<0.001$ & $<0.001$ & $>0.7$ \\
STY-6 & Uninoculated & 4.0 & 57.9 & 70 \\
& Inoculated & 2.1 & 32.5 & 65 \\
& $P$ & $<0.001$ & $<0.001$ & $>0.1$ \\
STY-7 & Uninoculated & 7.3 & 79.7 & 91 \\
& Inoculated & 4.0 & 44.2 & 90 \\
& $P$ & $<0.001$ & $<0.001$ & $>0.1$ \\
\hline
\end{tabular}

${ }^{\mathrm{z}}$ Significance by unpaired $t$ test between inoculated and uninoculated plants. environment: greenhouse conditions of plant inoculation and growth, as well as under field conditions. It is relatively quick, as results can be obtained 4 weeks after inoculation. Moreover, this scale can be used to assess the resistance level of a line or hybrid, as well as for screening the resistance level in a segregating population (such as a segregating F2 population following a cross between a resistant and a susceptible genotypes) of TYLCVresistant plants. Although the scale introduced here is composed of seven different genotypes, it is not essential to use all seven of them. It is possible to use only five of the scale genotypes, for instance STY-1, STY-2, STY-4, STY-5, and STY-7, in order to assess the resistance level of a given plant genotype.

Therefore, it is proposed that to evaluate the resistance level of a given tomato genotype to TYLCV, the genotype in question be inoculated alongside the differential hosts that define the scale, and within 4 weeks the level of resistance of the tested genotype can be determined according to its position on the resistance scale.

\section{ACKNOWLEDGMENTS}

We thank M. Friedmann and M. Pilowsky (Volcani Center, ARO) for their help in producing the STY lines, and S. Cohen and V. Gaba (Volcani Center, ARO) for critically reviewing this manuscript. This work was partially supported by the USAID-MERC grant no. M21-037. Contribution from the Agricultural Research Organization, the Volcani Center, Bet Dagan, Israel. Number 108/2006.

\section{LITERATURE CITED}

1. Antignus, Y., Nestel, D., Cohen, S., and Lapidot, M. 2001. Ultravioletdeficient greenhouse environment affects whitefly attraction and flight behavior. Environ. Entomol. 30:394-399.

2. Cohen, S., and Antignus, Y. 1994. Tomato yellow leaf curl virus, a whitefly-borne geminivirus of tomatoes. Adv. Dis. Vector Res. 10:259-288.

3. Cohen, S., and Harpaz, I. 1964. Periodic, rather than continual acquisition of a new tomato virus by its vector, the tobacco whitefly (Bemisia tabaci Gennadius). Entomol. Exp. Appl. 7:155-166.

4. Cohen, S., and Nitzany, F. E. 1966. Transmission and host range of tomato yellow leaf curl virus. Phytopathology 56:1127-1131.

5. Friedmann, M., Lapidot, M., Cohen, S., and Pilowsky, M. 1998. A novel source of resistance to tomato yellow leaf curl virus exhibiting a symptomless reaction to viral infection. J. Am. Soc. Hortic. Sci. 123:10041007.

6. Hilje, L., Costa, H. S., and Stansly, P. A. 2001. Cultural practices for managing Bemisia tabaci and associated viral diseases. Crop Prot. 20:801812.

7. Lapidot, M., and Friedmann, M. 2002. Breeding for resistance to whitefly-transmitted geminiviruses. Ann. Appl. Biol. 140:109-127.

8. Lapidot, M., Friedmann, M., Lachman, O., Yehezkel, A., Nahon, S., Cohen, S., and Pilowsky, M. 1997. Comparison of resistance level to tomato yellow leaf curl virus among commercial cultivars and breeding lines. Plant Dis. 81:1425-1428.

9. Lapidot, M., Goldray, O., Ben Joseph, R., Cohen, S., Friedmann, M., Shlomo, A., Nahon, S., Chen, L., and Pilowsky, M. 2000. Breeding tomatoes for resistance to tomato yellow leaf curl begomovirus. Bull. OEPP 30:317-321.

10. Laterrot, H. 1992. Resistance genitors to tomato yellow leaf curl virus (TYLCV). Tomato Leaf Curl Newsl. 1:2-4.

11. Nakhla, M. K., and Maxwell, D. P. 1998. Epidemiology and management of tomato yellow leaf curl virus. Pages 565-583 in: Plant Virus Disease Control. A. Hadidi, R. K. Khetarpal, and H. Koganezawa, eds. The American Phytopathological Society, St. Paul, MN.

12. Navot, N., Pichersky, E., Zeidan, M., Zamir, D., and Czosnek, H. 1991. Tomato yellow leaf curl virus: A whitefly-transmitted geminivirus with a single genomic component. Virology 185:131-161.

13. Palumbo, J. C., Horowitz, A. R., and Prabhaker, N. 2001. Insecticidal control and resistance management for Bemisia tabaci. Crop Prot. 20:739-766.

14. Pico, B., Diez, M., and Nuez, F. 1998. Evaluation of whitefly-mediated inoculation techniques to screen Lycopersicon esculentum and wild relatives for resistance to tomato yellow leaf curl virus. Euphytica 101:259-271.

15. Pico, B., Diez Maria, J., and Nuez, F. 1996. Viral diseases causing the greatest economic losses to the tomato crop. II: The tomato yellow leaf 
curl virus-A review. Sci. Hortic. 67:151-196.

16. Pico, B., Ferriol, M., Diez, M., and Nuez, F. 1999. Developing tomato breeding lines resistant to tomato yellow leaf curl virus. Plant Breed. 118:537-542.

17. Pilowsky, M., and Cohen, S. 1990. Tolerance to tomato yellow leaf curl virus derived from Lycopersicon peruvianum. Plant Dis. 74:248-250.

18. Polston, J. E., and Anderson, P. K. 1997. The emergence of whiteflytransmitted geminiviruses in tomato in the western hemisphere. Plant Dis. 81:1358-1369.
19. Polston, J. E., McGovern, R. J., and Brown, L. G. 1999. Introduction of tomato yellow leaf curl virus in Florida and implications for the spread of this and other geminiviruses of tomato. Plant Dis. 83:984-988.

20. Vidavsky, F., Leviatov, S., Milo, J., Rabinowitch, H. D., Kedar, N., and Czosnek, H. 1998. Response of tolerant breeding lines of tomato, Lycopersicon esculentum, originating from three different sources (L. peruvianum, $L$. pimpinellifolium and $L$. chilense) to early controlled inoculation by tomato yellow leaf curl virus (TYLCV). Plant Breed. 117:165-169. 